\title{
The City as a Socio-economic and Natural System
}

\author{
Stela Todorova ${ }^{1, *}$, Kaloyan Haralampiev ${ }^{2}$, and Aneliya Parzhanova ${ }^{3}$ \\ ${ }^{1}$ EDP Sciences, Department of Management and Marketing Department, Plovdiv, Bulgaria \\ ${ }^{2}$ EDP Sciences, Department of Sociology, Sofia, Bulgaria \\ ${ }^{3}$ EDP Sciences, Department of Administration \&Management, Varna, Bulgaria
}

\begin{abstract}
The modern city is increasingly seen as a socio-economic and natural system - they must be seen as complex entities. They differ in their development and size. Their identity, though rooted in history, is constantly changing. Over time they have undergone evolution caused by new needs. The modern city is a mirror of socio-economic problems, on the one hand. When exploring the city, it is necessary to apply a holistic approach and consider it as a system. The aim of this study is to develop a complex indicator for urban development which requires the application of a methodology for normalization, categorization and aggregation of data. The obtained result gives a concrete assessment of the development of the city in numerical expression on the basis of complex criteria, which allows adequate and clear comparison between the cities.
\end{abstract}

\section{Introduction}

In the etymological origin of the word citta (Italian), cite (French), ciudad (Spanish), (rooted in the Latin "civitas") are two fundamental semantic components - the city as a material, archaeological, topographical and urban. concept - as a human center, and the city according to the Italian encyclopedia Treccani as a "historical and legal phenomenon that has emerged as a characteristic core of society." The Greek word "polis" also contains two concepts - the medieval territorial meaning of a collection of buildings and spaces, and the legal meaning of a human community organized politically to achieve common goals.

Currently, the city is increasingly identified with the "municipality" (municipality, commune, muni-cipio, Gemeinde, comune), understood as an "autonomous territorial formation comprising a community of residents with certain interests", a "settlement center" with organized construction, utilities and own administration ". However, cities are complex entities. They differ significantly in their development and size. Their identity, though rooted in history, is constantly changing. Over time, most cities have evolved due to new needs, ideals, lifestyles, living standards, and quality of life. Urbanization and urban sprawl are creating new problems. As early as the beginning of the 19th century, and thanks to the Industrial Revolution, millions of people moved to the cities, attracted by the opportunity to find work and accumulate material and spiritual gains, turning their backs on their poverty.

This process is still ongoing in many European countries. In others, especially in recent years, there has been decentralization and reverse migration from the city to areas close to the city - suburbs, settlements, and not only on weekends, but for longer - in search of a healthier, less polluted environment, a new job or more coziness and comfort [1].

The tendency to increase the share of the urban population leads to the transformation of cities into economic and administrative centers, as well as to places where the main functions of the human life cycle habitation, work, recreation, servicing and related technical infrastructure - are prioritized [2].

\section{City as a socio-economic and eco- system}

The modern city is considered as a socio-economic and ecosystem. Urban spaces for living, recreation, work and transport need to be built and operate in an integrated network. With the emergence of spatial segregation, isolation and impaired accessibility, urban fabric is destroyed, its vulnerability increases and its sustainability decreases. The problems in the socio-economic sphere of the city are also a projection on space and complicate the possibilities for sustainability of the urban structure. All this presupposes the search for and substantiation of generalized indicators for sustainable development, called indicators and indices, which characterize the state, dynamics and interaction between the social, economic and ecosystem.

Parameters and criteria for the sustainability of the city according to the UN formulations include the following components of the sustainability of the built environment [3]:

- social component - characteristics, development and management of human resources as an urbanized society;

\footnotetext{
* Corresponding author: stelatodorova_au@hotmail.com
} 
- economic component - macro- and microeconomic frameworks of development of the city and the urbanized territories;

- natural component - ecologically treated natural environment, developed in balance with the built environment;

- security component - preventive organizational, institutional, legislative and financial measures to anticipate risk and reduce vulnerability to the impact of destructive natural, technological and anthropogenic factors on urban areas.

According to Peter Marinov each system or subsystem must be developed and operated solely in the direction of an environmentally sound lifestyle. The symbiosis between society and the natural environment can function in an urban environment [4].

Sustainable development is separated into an independent area, to which a number of special international forums are dedicated, which address the issues of environmental indicators and indices. As a result of the joint efforts of scientists from many countries around the world, agreement has been reached on the common basic characteristics (criteria) that these indicators must have. For the following four characteristics are accepted: (1) sensitivity, (2) aggregation ability, (3) clarity of interpretation, and (4) scientific validity.

It should be noted that the criteria on the basis of which certain indicators are declared as indicators are largely unjustified, and the values introduced in the role of indicators very often do not satisfy the above four main requirements. All this inevitably leads to dilution and a sharp increase in the number of indicators themselves, which further complicates their definition instead of limiting and unifying information, there is an expansion of its scope and volume, and hence an increase in uncertainty. In addition, the possibilities for aggregation of indicators relating to even the same field of study are reduced, clarity and simplicity of interpretation are lost and management decisions are made more difficult. On the other hand, there are practical difficulties in developing these indicators, which stem from the lack of data, local potential, dialogue between scientists and decision-makers.

The successfully identified indicators for sustainable development in their respective hierarchical arrangement allow the development of systems of models aimed at creating a unified methodological apparatus. It must provide an opportunity for mathematical processing and to obtain a compact summary of the quality of the environment and its interaction with the socio-economic subsystems. The main purpose of the introduction of the indicators is the assessment and characterization of the condition and the situation in certain directions of observation (for example in social, economic, environmental and other aspects).

In the presence of a certain indicator and its values for different compared objects (in time and / or space), the difference between these values serves to characterize the degree of deviation. Measured in relative form, this degree of deviation is determined as an "index", which corresponds to the semantic content of the concept.
Indeed, translated from Latin, "index" means an indicator that characterizes the relative difference of a quantity with respect to a level accepted as a basis for comparison. At least two values are required for the construction of an index, each of which is a specific value of a given indicator. From this point of view, the indicators are those "elementary particles" from which the indices are formed.

In the present study, the term "indicator" is defined as a quantitative quantity that expresses the state of a studied phenomenon (process) and gives an idea of the expected direction for changes in it. The indicator covers the primary data from conducted observations on complex phenomena, presenting in a form allowing its generalization through complex measures (indices).

The creation of a unified system of indicators will allow for the collection of homogeneous information, allowing the preparation of comparative analyzes and monitoring of individual and general trends in urban development in the context of national, European and world economic and geopolitical environment. In order for the system of indicators to be clear and transparent, it is necessary to be accompanied by a specific methodology, indicating how the indicator is calculated, where the source information about it is taken from, etc.

The aim of this study is to develop a complex indicator for urban development which requires the application of a methodology for normalization, categorization and aggregation of data. The obtained result gives a concrete assessment of the development of the city in numerical expression on the basis of complex criteria, which allows adequate and clear comparison between the cities.

\section{Methodological framework: the construction of the composite index.}

Since there are not available data on city/town level, we calculated the percentage of the municipality center population toward the entire municipality population according the data from the National Census as shown in Table 1 . We decided to use only the municipalities in which more than $90 \%$ of population live in the municipality center. Thus, the data about the municipality are good approximation for the municipality center.

Table 1. Percentage of the population in the municipality centres

\begin{tabular}{|ll|c|c|}
\hline Municipality & Population & $\begin{array}{c}\text { Percentage of the } \\
\text { population in the } \\
\text { municipality center }\end{array}$ \\
\hline 1. & Plovdiv & 338153 & $100,0 \%$ \\
\hline 2. & Dobrich & 91030 & $100,0 \%$ \\
\hline 3. & Yambol & 74132 & $100,0 \%$ \\
\hline 4. & Krichim & 8409 & $100,0 \%$ \\
\hline 5. & Perushtitsa & 5058 & $100,0 \%$ \\
\hline 6. & Dolna Banya & 4522 & $100,0 \%$ \\
\hline 7. & Koprivshtitsa & 2410 & $100,0 \%$ \\
\hline
\end{tabular}




\begin{tabular}{|ll|c|c|}
\hline 8. & Varna & 343704 & $97,4 \%$ \\
\hline 9. & Burgas & 212902 & $94,1 \%$ \\
\hline 10. & Sofia & 1291591 & $93,1 \%$ \\
\hline 11. & Devnya & 8730 & $91,8 \%$ \\
\hline 12. & Blagoevgrad & 77441 & $91,5 \%$ \\
\hline 13. & Kuklen & 6431 & $91,1 \%$ \\
\hline 14. & Apriltsi & 3338 & $90,4 \%$ \\
\hline 15. & Gabrovo & 65268 & $90,3 \%$ \\
\hline 16. & Pirdop & 8293 & $90,3 \%$ \\
\hline
\end{tabular}

Source: National Statistical Institute of Bulgaria

For each municipality we gathered data about 76 indicators aggregated in 8 dimensions (see Fig. 1). The number of indicators by dimensions is shown in a Table 2 . Our data sources are National Statistical Institute of Bulgaria and Employment Agency. The study covers the period 2011-2019.

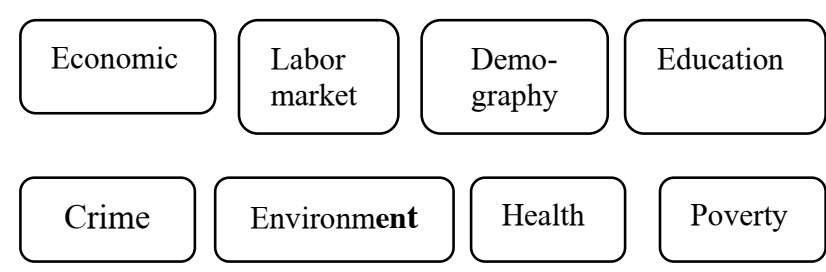

Fig. 1. Categorization of the indicators that make up the Urban Development Index

Table 2. Number of the indicators by dimensions

\begin{tabular}{|c|c|}
\hline Dimension & Number of the indicators \\
\hline Economic & 1 \\
\hline Labor market & 2 \\
\hline Demography & 11 \\
\hline Education & 32 \\
\hline Crime & 2 \\
\hline Environment & 5 \\
\hline Health & 15 \\
\hline Poverty & 8 \\
\hline Total & 76 \\
\hline
\end{tabular}

For each dimension we constructed sub-index in the following way:

1. Since each one of the indicators has its own substantive unit of measurement, the first step in the analysis is to make all the indicators comparable despite their substantive diversity and the subsequent variety of measurements involved. There are several well-known ways of solving this uneasy task. The most popular are standardization (z-scores), normalization and ranking. We chose the approach based on ranks, similar to those proposed by Kendal [5], Dimitrov et al. [6], Haralampiev, Dimitrov [7], Todorova [8]. We ranked all municipalities according to the respective values of the initial indicators. If the indicator is positive (such as "Employees per 1000 population") then we ranked it in increasing order. If the indicator is negative (such as "Unemployment rate") then we ranked it in decreasing order. Thus, we have $m$ rankings of 16 municipalities.

2.For each municipality we calculated average rank.
3.For each municipality we normalized the average ranks using the equation:

$$
\begin{aligned}
\text { Subindex } & =\frac{\text { Average rank }-1}{16-1} .100 \\
= & \frac{\text { Average rank }-1}{15} .100
\end{aligned}
$$

Thus, we obtain index numbers, which are between 0 and 100 .

When we construct a composite indicator from the set of many diverse indicators one general question arises: "Are all the initial indicators consistent with each other?" In order to answer this question, we use Kendal's coefficient of concordance $W$ :

$$
W=\frac{\sum_{i=1}^{n}\left(\sum_{j=1}^{m} r_{i j}-\frac{\sum_{i=1}^{n} \sum_{j=1}^{m} r_{i j}}{n}\right)^{2}}{\frac{1}{12} m^{2}\left(n^{3}-n\right)-\frac{1}{12} m \sum_{T^{\prime}}\left(t^{3}-t\right)}
$$

Where is the rank of $\mathrm{i}$-the municipality in the $\mathrm{j}$-th ranking, $T^{\prime}$ is the number of repetitions of ranks and $t$ is the number of the repeated ranks in each repetition [4]. In our case:

$$
\begin{gathered}
\frac{\sum_{i=1}^{n} \sum_{j=1}^{m} r_{i j}}{n}=\frac{\sum_{j=1}^{m} \sum_{i=1}^{16} r_{i j}}{16}=\frac{\sum_{j=1}^{m} 136}{16}=\frac{136 m}{16} \\
=8.5 m \\
n^{3}-n=16^{3}-16=4080
\end{gathered}
$$

Hence:

$$
\begin{aligned}
W=\frac{\sum_{i=1}^{n}\left(\sum_{j=1}^{m} r_{i j}-8.5 m\right)^{2}}{\frac{4080}{12} m^{2}-\frac{1}{12} m \sum_{T \prime}\left(t^{3}-t\right)} \\
=\frac{\sum_{i=1}^{n}\left(\sum_{j=1}^{m} r_{i j}-8.5 m\right)^{2}}{340 m^{2}-\frac{1}{12} m \sum_{T \prime}\left(t^{3}-t\right)}
\end{aligned}
$$

Kendal suggests a framework for interpretation of the concordance coefficient: "W measures, in a sense, the communality of judgments for the $m$ observers. If they are all agree,. If they differ very much among themselves, the sums of ranks will be more or less equal [...] so $\mathrm{W}$ is small. As $\mathrm{W}$ increases from 0 to 1 the deviations become 'more different' and there is a greater measure of agreement in the rankings" [5].

There are two important points that should be emphasized in this interpretation: 
- Kendal speaks about observers while we consider indicators. In fact, such an approach is used mainly when the ranks are assigned by the "observers" or "raters" [9]. In our case, the initial indicators perform the same role as raters - they rank the municipalities.

- Kendal states that if the raters "differ very much among themselves the sums of ranks will be more or less equal." This is very important because if there are indicators, which are not consistent with the others, then the concordance will be weak.

On the other hand Kendal gives a relation between the coefficient of concordance $\mathrm{W}$ and the mean value of the Spearman's rank correlation $\left(\rho_{a v}\right)$ between the $\left(\begin{array}{c}m \\ 2\end{array}\right)$ pairs of observers [4]:

$$
\rho_{a v}=\frac{m W-1}{m-1}
$$

Hence (Gwet, 2014, p. 363):

$$
W=\frac{(m-1) \rho_{a v}+1}{m}
$$

Or:

$$
W=\rho_{a v}-\frac{\rho_{a v}-1}{m}
$$

In theory, this relation allows increasing of $\mathrm{W}$ if we remove some indicator(s), which are weakly correlated with the other(s). Instead of calculating all the Spearman's coefficients for all possible pairs of initial indicators, we calculated only $\mathrm{m}$ Spearman coefficients between each initial indicator and the sub-index of the respective municipality. Thus, we reduce the computing work.

4. Therefore, we first used the Spearman's rank correlation to identify which indicators are not consistent with the others. We remove the indicators, which correlate weak or moderate with the sub-index. If there are values of the Spearman's correlation below 0,667 we remove the indicator with the smallest value.

5. We repeated points 2, 3 and 4 until all Spearman's rank correlations becomes larger than or equal to 0,667 .

Thus, we obtained the following list of indicators by dimensions which can be seen in Table 3 .

\begin{tabular}{|c|c|}
\hline Indicators & $\begin{array}{c}\text { Spearman's } \\
\text { correlation with } \\
\text { sub-index } \\
\end{array}$ \\
\hline Population growth per 1000 population & 0,939 \\
\hline $\begin{array}{l}\text { Coefficient of age dependence } \\
\text { (seniors) }\end{array}$ & 0,914 \\
\hline Deaths per 1000 population & 0,893 \\
\hline $\begin{array}{l}\text { Net internal migration per } 1000 \\
\text { population }\end{array}$ & 0,752 \\
\hline \multicolumn{2}{|l|}{ Education } \\
\hline $\begin{array}{l}\text { Students in programs for acquiring the } \\
\text { second degree of professional } \\
\text { qualification per } 1000 \text { population }\end{array}$ & 0,972 \\
\hline $\begin{array}{l}\text { Classes in programs for acquiring the } \\
\text { second degree of professional } \\
\text { qualification per } 1000 \text { population }\end{array}$ & 0,960 \\
\hline $\begin{array}{l}\text { Graduated in programs for acquiring } \\
\text { the second degree of professional } \\
\text { qualification per } 1000 \text { population }\end{array}$ & 0,944 \\
\hline $\begin{array}{l}\text { Newly admitted in programs for } \\
\text { acquiring the second degree of } \\
\text { professional qualification per } 1000 \\
\text { population } \\
\end{array}$ & 0,940 \\
\hline $\begin{array}{c}\text { Graduated V-VII in general and special } \\
\text { schools per } 1000 \text { population }\end{array}$ & 0,890 \\
\hline $\begin{array}{c}\text { Classes V-VII in general and special } \\
\text { schools per } 1000 \text { population }\end{array}$ & 0,703 \\
\hline \multicolumn{2}{|l|}{ Crime } \\
\hline $\begin{array}{c}\text { Crimes ending in a conviction per } \\
1000 \text { population }\end{array}$ & 0,999 \\
\hline Convicted persons per 1000 population & 0,999 \\
\hline \multicolumn{2}{|l|}{ Environment } \\
\hline $\begin{array}{l}\text { Submitted for pre-treatment household } \\
\text { waste per } 1000 \text { population }\end{array}$ & 0,883 \\
\hline $\begin{array}{l}\text { Household waste handed over for } \\
\text { recycling per } 1000 \text { population }\end{array}$ & 0,789 \\
\hline $\begin{array}{c}\text { Proportion of points with noise levels } \\
\text { above the permissible norms }\end{array}$ & 0,750 \\
\hline $\begin{array}{l}\text { Directly disposed household waste per } \\
1000 \text { population }\end{array}$ & 0,724 \\
\hline \multicolumn{2}{|l|}{ Health } \\
\hline Population per one doctor & 0,928 \\
\hline Doctors per 1000 population & 0,925 \\
\hline $\begin{array}{l}\text { Medical specialists in Health Care per } \\
1000 \text { population }\end{array}$ & 0,904 \\
\hline Beds in hospitals per 1000 population & 0,864 \\
\hline $\begin{array}{l}\text { Medical institutions for outpatient care } \\
\text { per } 1000 \text { population }\end{array}$ & 0,840 \\
\hline Dentists per 1000 population & 0,824 \\
\hline Population per one dentist & 0,815 \\
\hline $\begin{array}{c}\text { Beds in outpatient care facilities per } \\
1000 \text { population }\end{array}$ & 0,763 \\
\hline $\begin{array}{l}\text { Beds in other medical and health } \\
\text { establishments per } 1000 \text { population }\end{array}$ & 0,747 \\
\hline $\begin{array}{c}\text { Other medical and health } \\
\text { establishments per } 1000 \text { population }\end{array}$ & 0,738 \\
\hline $\begin{array}{l}\text { Medical institutions for hospital care } \\
\text { per } 1000 \text { population }\end{array}$ & 0,676 \\
\hline \multicolumn{2}{|l|}{ Poverty } \\
\hline Percentage of poor & 0,976 \\
\hline Percentage of poor adults ( $65+$ years) & 0,956 \\
\hline Percentage of poor adults (15-64 years) & 0,947 \\
\hline Percentage of working poor & 0,929 \\
\hline $\begin{array}{l}\text { Percentage of poor with primary and } \\
\text { lower education }\end{array}$ & 0,924 \\
\hline $\begin{array}{c}\text { Percentage of poor children ( } 0-14 \\
\text { years) }\end{array}$ & 0,821 \\
\hline
\end{tabular}

Table 3. Indicators by dimensions

\begin{tabular}{|c|c|}
\hline Indicators & $\begin{array}{c}\text { Spearman's } \\
\text { correlation with } \\
\text { sub-index }\end{array}$ \\
\hline \multicolumn{2}{|c|}{ Economic } \\
\hline Enterprises per 1000 population & 1,000 \\
\hline Labor market \\
\hline Employees per 1000 population & 0,922 \\
\hline Unemployment rate & 0,916 \\
\hline Demography & 0,949 \\
\hline Coefficient of age dependence &
\end{tabular}




\begin{tabular}{|c|c|}
\hline Indicators & $\begin{array}{c}\text { Spearman's } \\
\text { correlation with } \\
\text { sub-index }\end{array}$ \\
\hline $\begin{array}{c}\text { Percentage of poor with secondary } \\
\text { education }\end{array}$ & 0,791 \\
\hline $\begin{array}{c}\text { Percentage of poor with tertiary } \\
\text { education }\end{array}$ & 0,780 \\
\hline
\end{tabular}

Source: Own calculation

Table 4. Coefficient of concordance by dimensions

\begin{tabular}{|l|c|c|}
\hline \multicolumn{1}{|c|}{ Dimension } & $\begin{array}{c}\text { Number of } \\
\text { indicators }\end{array}$ & $\begin{array}{c}\text { Coefficient of } \\
\text { concordance }\end{array}$ \\
\hline Economic & 1 & 1,000 \\
\hline Labor market & 2 & 0,860 \\
\hline Demography & 5 & 0,798 \\
\hline Education & 6 & 0,818 \\
\hline Crime & 2 & 0,997 \\
\hline Environment & 4 & 0,622 \\
\hline Health & 11 & 0,693 \\
\hline Poverty & 8 & 0,808 \\
\hline
\end{tabular}

Source: Own calculation

All Kendal's coefficients of concordance show strong concordance (see Table 4).

After that, we calculated the entire index as average of the sub-indices. However, Kendal's coefficient of concordance is 0,393 , which is weak concordance. The main reason is that the sub-indices for Education and Crime are not consistent with the others. After their removing, Kendal's coefficient of concordance becomes 0,724 . The final results are presented in Table 5.

\section{Result and discussion}

The indicators we offer in order to characterize the socioeconomic and environmental sustainability of cities have been grouped into topics for which relevant indicators are indicated.

To determine the model for the development of a city, we define a composite indicator, which covers the main socio-economic and environmental parameters that form the development of cities.

Table 5. Index and sub-indices

\begin{tabular}{|l|c|c|c|c|c|c|c|}
\hline $\begin{array}{l}\text { Munici- } \\
\text { pality }\end{array}$ & $\begin{array}{c}\text { Eco- } \\
\text { nomi } \\
\text { c }\end{array}$ & $\begin{array}{c}\text { Labo } \\
\text { rark } \\
\text { mat }\end{array}$ & $\begin{array}{c}\text { Dem- } \\
\text { o- } \\
\text { gra- } \\
\text { phy }\end{array}$ & $\begin{array}{c}\text { Envi- } \\
\text { ron } \\
\text { ment }\end{array}$ & $\begin{array}{c}\text { Healt } \\
\text { h }\end{array}$ & $\begin{array}{c}\text { Po- } \\
\text { ver- } \\
\text { ty }\end{array}$ & $\begin{array}{c}\text { Inde } \\
\mathbf{x}\end{array}$ \\
\hline Sofia & 100 & 100 & 89,3 & 91,7 & 73,9 & 97,5 & 92,1 \\
\hline Varna & 86,7 & 83,3 & 90,7 & 86,7 & 82,4 & 72,1 & 83,6 \\
\hline Plovdiv & 73,3 & 83,3 & 82,7 & 80,8 & 86,1 & 59,6 & 77,6 \\
\hline Burgas & 80 & 70 & 69,3 & 61,7 & 73,3 & 81,7 & 72,7 \\
\hline $\begin{array}{l}\text { Blagoev- } \\
\text { grad }\end{array}$ & 93,3 & 60 & 84 & 50 & 80,6 & 67,5 & 72,6 \\
\hline Dobrich & 53,3 & 56,7 & 36 & 67,5 & 57,6 & 50 & 53,5 \\
\hline Gabrovo & 66,7 & 63,3 & 18,7 & 70 & 65,2 & 23,8 & 51,3 \\
\hline Devnya & 20 & 73,3 & 62,7 & 50,8 & 30,9 & 57,5 & 49,2 \\
\hline Yambol & 40 & 60 & 41,3 & 53,3 & 57,9 & 41,3 & 49 \\
\hline
\end{tabular}

\begin{tabular}{|l|c|c|c|c|c|c|c|} 
Pirdop & 33,3 & 43,3 & 17,3 & 22,5 & 57,6 & 95,8 & 45 \\
\hline Kuklen & 26,7 & 26,7 & 54,7 & 27,5 & 33,3 & 49,2 & 36,3 \\
\hline $\begin{array}{l}\text { Kopriv- } \\
\text { shtitsa }\end{array}$ & 46,7 & 30 & 9,3 & 22,5 & 15,2 & 45 & 28,1 \\
\hline Apriltsi & 60 & 26,7 & 8 & 14,2 & 22,4 & 22,9 & 25,7 \\
\hline $\begin{array}{l}\text { Dolna } \\
\text { Banya }\end{array}$ & 6,7 & 10 & 49,3 & 37,5 & 21,8 & 8,3 & 22,3 \\
\hline $\begin{array}{l}\text { Peru- } \\
\text { shtitsa }\end{array}$ & 13,3 & 10 & 32 & 30,8 & 21,8 & 17,9 & 21 \\
\hline Krichim & 0 & 3,3 & 54,7 & 32,5 & 20 & 10 & 20,1 \\
\hline
\end{tabular}

Source: Own calculation

As can be seen from the results shown in Table 5, the highest value has the composite index for the city of Sofia $(92,1)$. Here most of the sub-indices (economic, labor market, environment, poverty) are also the highest. This can be explained by the fact that Sofia is the capital of the country.

In second and third place are the cities of Varna $(83,6)$ and Plovdiv $(77,6)$, respectively. These cities and the corresponding sub-indices have approximately the same values. These are the two largest cities in the country after Sofia, which are well-known administrative and socio-economic centers.

The birth rate in 2005 in the municipality of Varna of $11,1 \%$ is higher than in Bulgaria 9.2\%o. Mortality is lower by $10,5 \%$ compared to $14,6 \%$ or for country. The natural increase is positive $0,6 \%$ while negative for Bulgaria of $-5,4 \%$. In 2006, the natural increase increased to $2,4 \%$. The population density in the municipality is high, 1510 people per sq. Km. at an average for Bulgaria of 70 hours / sq. km.

Plovdiv is one of the leading industrial centers in Bulgaria. The district ranks first in the country in terms of the number of employees in the manufacturing industry (over 69 thousand in 2014 [106]), which testifies to its strong industrial specialization. Industry is a major contributor to investment in the Plovdiv region. An example of this is the Thrace Economic Zone, which stands out as one of the largest economic projects in Bulgaria.

Burgas $(72,7)$ and Blagoevgrad $(72,6)$ also have relatively high and almost equal values of the composite index.

Burgas is the largest city in Southeastern Bulgaria and the second largest on the Bulgarian Black Sea coast, and with its land of $253,644 \mathrm{~km}$, it is the second largest city in Bulgaria (after Sofia). According to the latest census of the NSI as of December 31, 2019, the population is 203,299 inhabitants and thus continues to be the fourth largest city in the country (after Sofia, Plovdiv and Varna). Burgas is the most important cultural, economic, transport, management, tourist and educational center in Southeastern Bulgaria.

Blagoevgrad is an economic, cultural and educational center of Southwestern Bulgaria and an administrative center of the district and municipality of the same name. According to the census of the National Statistical Institute as of December 31, 2018, the city has a population of 69,178 people. Due to the large number of 
students (partly due to the American University in the city), its crossroads geographical location, nature and a number of social factors, the city has a relatively welldeveloped economy.

The composite index has its advantages and disadvantages, which derive partly from the very nature of composite indicators and their original characteristics and partly from the specifics of the development of this indicator.

The indices of the other cities in descending order can be seen from Table 5. Blagoevgrad is followed by Dobrich, Gabrovo, Devnya, Yambol and Pirdop. Then the index sharply decreases its values and last in the ranking is Krichim.

Advantages:

$\checkmark$ The index builds a complex picture for the development of the city;

$\checkmark \quad$ It is easier to interpret;

$\checkmark$ Summarizes information on the social, economic and environmental condition of cities;

$\checkmark$ Gives the opportunity to compare the cities on the same generalized indicator.

$\checkmark \quad$ It is possible to compare the indicator over time.

Disadvantages:

$\checkmark$ If not constructed well, it can lead to distortion of information;

$\checkmark$ The choice of indicators and weights can be subjective.

\section{Conclusion}

It can definitely be said that as far as there are practical efforts to use indicators in Bulgarian municipalities, they are subordinated rather to the first point of view. Indicative is the fact that none of the municipalities uses the UN-approved methodology on the basis of which settlement indicators could be transformed and aggregated at the national level. From here one can outline a characteristic one peculiarity of the Bulgarian practice - the search for a universal set of indicators for local sustainable development is not a priority. Each territorial community in Bulgaria, according to its own goals, needs and resources, as well as the vision of certain members for its present and future, independently prepares its own set of indicators for sustainable development, covered in certain categories.

At the same time indicators are not a new tool in urban planning in Bulgaria - they are provided and implemented in each Integrated Plan for Urban Reconstruction and Development to currently following the methodology established at the national level. However, they are specific to each urban system, which does not allow comparison between cities and allows the loss of valuable information. The indicators can be applied in practice for all cities in the country. The more cities get involved, the more complete will be the picture of the interconnections between the settlements in Bulgaria and their development trends. This will answer two main questions: What progress have cities made towards more sustainable development than in the past and compared to other cities?
Which factors are drivers of growth and which local resources could be better mobilized to increase growth and better living conditions for people?

This research was supported by Bulgarian National Science Fund grand.

\section{References}

1. Charter of European Cities, Council of Europe, Congress of Local and Regional Authorities, Strasbourg, Foundation for Local Government Reform, Sofia, p. 9, (1992, 2000)

2. K. Petrov, Theoretical Approaches to the Regional Development Policy and Geo-Urbanistic in Bulgaria Volume 9 Issue 9, ISSN: 2319-7064 (2020)

3. Indicators of Sustainable Development: Framework and Methodology. N.Y.: United Nations (1996)

4. P. Marinov, Formation and implementation of sustainable development in Green infrastructure of urbanized Urban spaces, Jubilee International Science conference Economic science, Education and Real Economy: Development and Interactions in the digital age 11-12.05.2020., Varna, Volume II, p. 739-747, “UPH-Varna", ISBN 978-954-21-1038-5 (2020)

5. M. Kendal, Rank correlation methods. (Fourth edition). London: Griffin (1970)

6. G. Dimitrov, K. Haralampiev, T. Angelova, A. Grozdev, Z. Georgiava. Policies for Science in Sofia University "St. Kliment Ohridski". Sofia: St. Kliment Ohridski University Press, ISBN 978-95407-3408-8 (2012)

7. K. Haralampiev, G. Dimitrov, Quantitative research approaches in support of the new EC's framework to safeguard the rule of law in EU. Regions \& Cohesion, Volume 6, Issue 3, Winter 2016: 19-50, doi: 10.3167/reco.2016.060302, ISSN 2152-906X (Print), ISSN 2152-9078 (2016)

8. Todorova, E., Information provision of integrated urban planning. Doctoral dissertation (2019)

9. K. Gwet., Handbook of inter-rater reliability. (Fourth edition). Gaithersburg: Advanced Analytics, LLC, p. 360-361, (2014) 